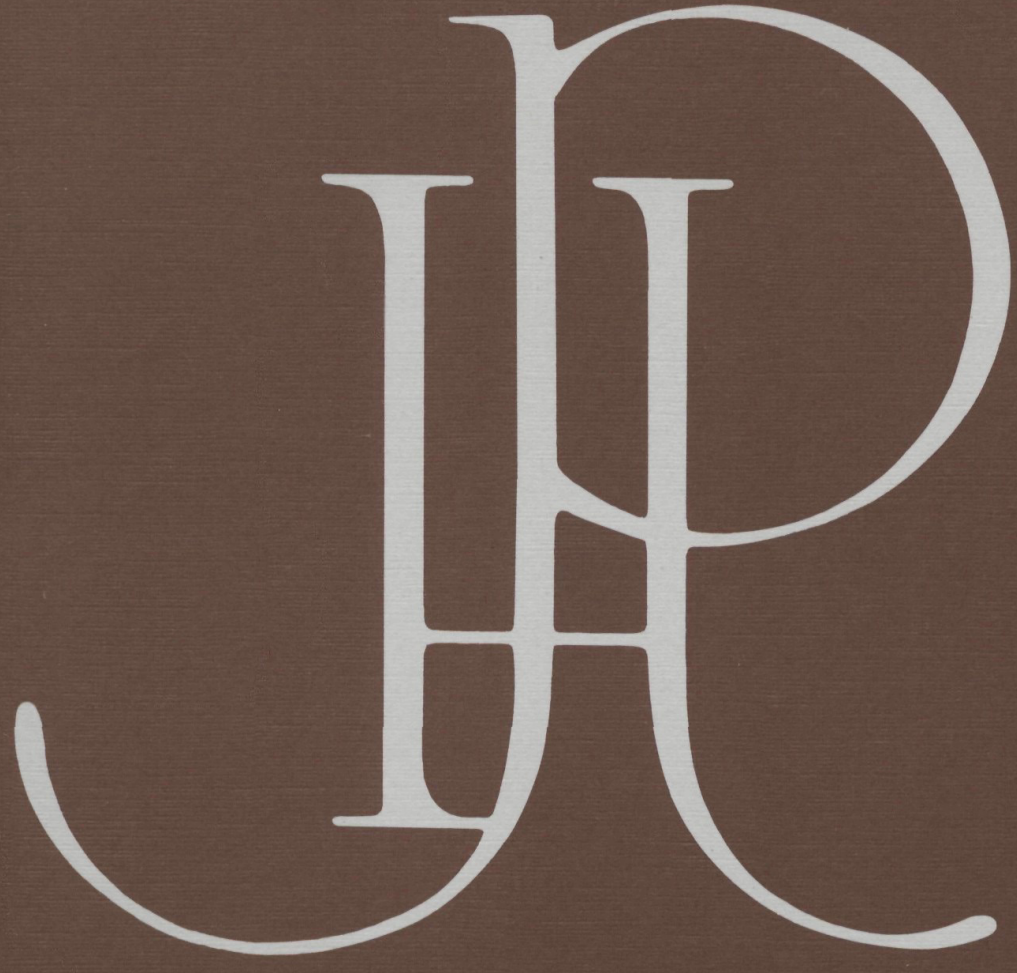

The Pennsylvania State University Press

Vol. 5, No. 31993
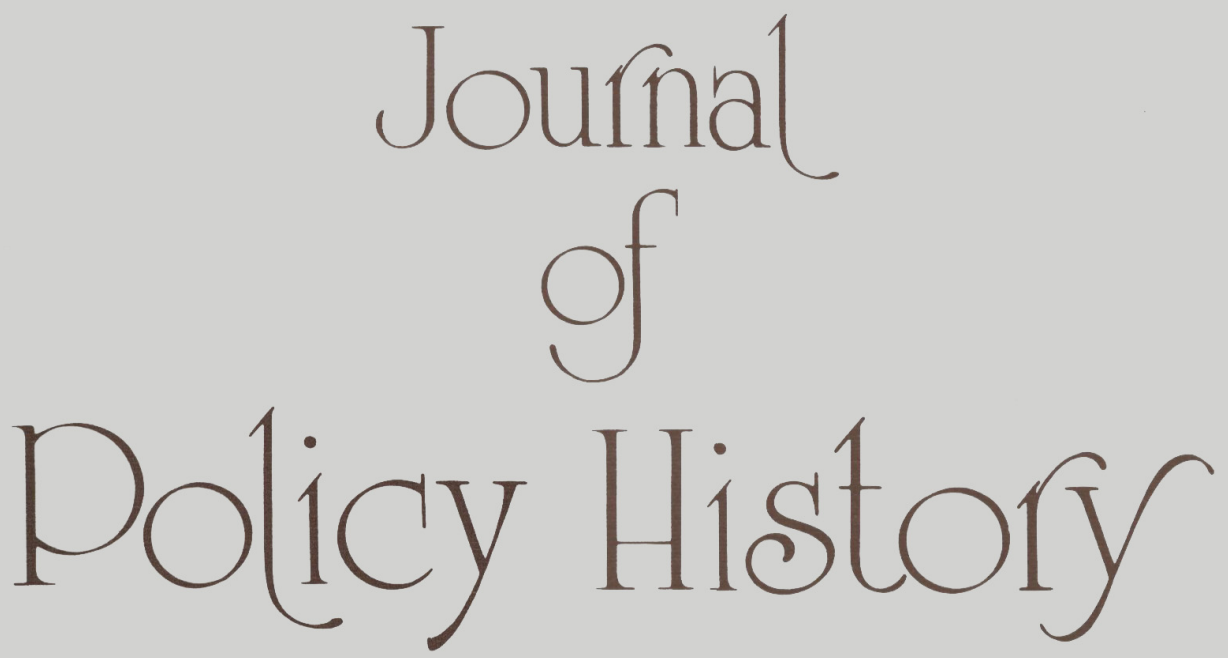
EDITOR

Donald T. Critchlow

Saint Louis University

ASSOCIATE EDITOR/BOOK REVIEW EDITOR

David B. Robertson

University of Missouri, St. Louis

MANAGING EDITOR

Thomas F. Curran

EDITORIAL ASSOCIATE

Duane G. Jundt

COPYEDITOR

Cherene Holland

\section{EDITORIAL ASSISTANT}

Aristide Sechandice

\section{EDITORIAL BOARD}

Andrew Achenbaum (Gerontology) Unipersity of Michigan

Douglas E. Ashford (Political Science) University of Pittsburgh

Edward Berkowitz (History) George Washington University

Martha Derthick (Government) University of Virginia

\section{Robert Friedman (Political Science)} Pennsylvania State University

David Garrow (Political Science) Twentieth Century Fund

Hugh Graham (History) Vanderbilt University

Otis Graham (History) University of California, Santa Barbara

Ellis Hawley (History) University of Iowa

Charles O. Jones (Political Science) University of Wisconsin
Ira Katznelson (Political Science) New School for Social Research

Morton Keller (History) Brandeis University

Robert Kelley (History) University of California, Santa Barbara

K. Austin Kerr (History) Obio State University

Ann S. Orloff (Sociology) University of Wisconsin

Theda Skocpol (Sociology) Harvard University

Alan Stone (Political Science) University of Houston

Aaron Wildavsky (Political Science) University of California, Berkeley

David Vogel (Business) University of California, Berkeley 


\section{Contents

\section{Articles}

DOUGLAS E. ASHFORD

The Historical and Political Foundations of the Welfare State:

A Lost Opportunity for the Left?

\section{GERALD BERK}

Adversarial by Design: Railroads and the American State, $1887-1916$

\section{Forum}

WILLIAM H. BECKER

The Impact of America's Becoming Corporate: A Review Essay

\section{Commentary}

LARRY G. GERBER

A Reply to William Becker

OLIVIER ZUNZ

A Reply to William Becker

MORTON KELLER

A Reply to William Becker

Book Reviews 


\section{Journal of Policy History}

The Journal of Policy History provides an interdisciplinary forum for scholars concerned with the application of historical perspectives to public policy studies. The journal aims to encourage research into the formation and development of public policy while encouraging the application of diverse methods and theories to public policy and their politics within a historical perspective. In addition to social scientists and historians, the journal seeks to inform policymakers through a historical approach to public policy.

The Journal of Policy History is intended to give voice to scholars interested in understanding public policies and their development through historical inquiry and interpretation. The Journal publishes historical studies of specific policy areas and policy institutions, and explores continuities and shifts in policy over time. The Journal encourages interdisciplinary research into the origins and development of public policy in the United States and other countries. Comparative historical approaches to the development of public policies are also welcomed.

Manuscripts should be typed double-spaced with end notes following the text and generally should not exceed 30 typewritten pages. Manuscripts accepted for publication will be reviewed anonymously, and authors' names, including positions, addresses, and phone numbers, should appear only on the title page. Any notes referring to the authors should be placed on a separate page to further maintain anonymity during the reviewing process. Four copies of a manuscript, together with an abstract of no more than 150 words and a biographical sketch of no more than 50 words, should be sent to the Editor, Journal of Policy History, 221 N. Grand Blvd., Saint Louis University, St. Louis, MO, 63103.

The Journal of Policy History (ISSN 0898-0306) is published quarterly by The Pennsylvania State University Press, Suite C, Barbara Building, University Park, PA 16802. Annual subscription rates: U.S.A.: Individuals $\$ 20 / y r$; Institutions $\$ 30 / y r$. Outside U.S.A.: Individuals, $\$ 27 / \mathrm{yr}$.; Institutions $\$ 35 / \mathrm{yr}$. All correspondence of a business nature, including subscriptions, permissions, advertisements, and changes of address, should be addressed to The Penn State Press. Subscribers are requested to notify the Press and their local postmaster immediately of change of address. POSTMASTER: Send address changes to the Penn State Press, Suite C, Barbara Building, University Park, PA 16802 and Ann Arbor, MI.

This journal is registered with the Copyright Clearance Center, 27 Congress Street, Salem, MA 01970. Libraries and other users registered with the CCC may photocopy any article in the journal provided that a base fee of $\$ 1.00$ per copy is paid directly to the CCC. This authorization does not extend to copies made for duplicating an entire issue, for creating anthologies, for advertising, or for reselling. For information about multiple copying for classroom use, write to the Permissions Manager, The Penn State Press, at the address above.

Copyright (C) 1993 by The Pennsylvania State University. All rights reserved. No copies may be made without written permission of the publisher. 


\section{Forthcoming Articles}

David T. Beito (University of Nevada, Las Vegas), "Mutual Aid, State Welfare, and Organized Charity: Fraternal Societies and the 'Deserving' and 'Undeserving' Poor, 1890-1930'

W. D. Kay (Northeastern University), "Where No Nation Has Gone Before: Domestic Politics and the First International Space Science Mission"

Charles O. Jones (University of Wisconsin, Madison), "Elitism, Think Tanks, and American Politics: A Review Essay"

Byron E. Shafer (Nuffield College), FORUM: "Political Eras in Political History"; with responses from Joel H. Silbey (Cornell University) and Paula Baker (University of Pittsburgh)

Marc Allen Eisner (Wesleyan University), "Institutional History and the Origins of Policy Change: Exploring Changes in Antitrust Policy"

Samuel B. Hoff (Delaware State College), "The Presidential Pocket Veto: Its Use and Legality"

\section{Special Issues}

Hugh Davis Graham (Vanderbilt University), Civil Rights (Winter 1994)

Donald T. Critchlow (Saint Louis University), "Birth Control and Reproduction" (Winter 1995) 